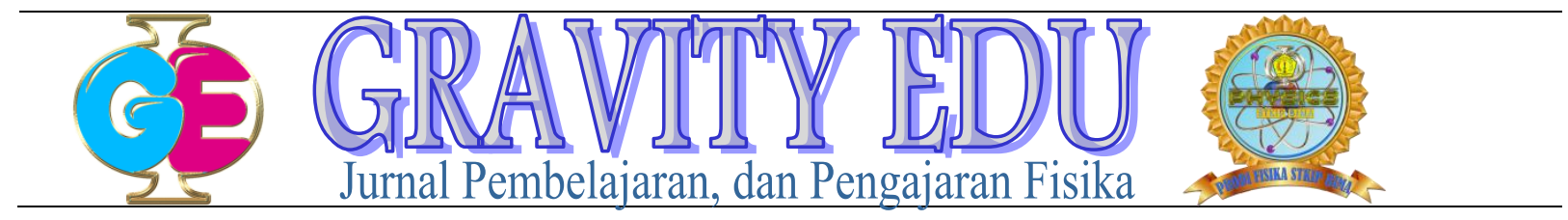

\title{
Pengaruh Pembelajaran Fisika Online Terhadap Sikap Belajar Siswa
}

\author{
Nurhafidah $^{1}$ dan Monika Herliyanti ${ }^{2}$ \\ ${ }^{1,2}$ ) Prodi Pendidikan Fisika, \\ FMIPA Universitas Indraprasta PGRI Jakarta \\ Email : lejapmonika@gmail.com
}

\begin{abstract}
ABSTRAK : Di Indonesia, perkembangan internet mengalami perkembangan yang cukup pesat. Hal tersebut dapat dilihat dari merebaknya berbagai penyedia jasa layanan internet, menjamurnya warung/kafe internet, dan keterjangkauan akses internet dari segi biaya. Dewasa ini teknologi internet sudah tidak dianggap barang mewah lagi, bahkan sudah menjadi kebutuhan. Internet menimbulkan dampak seperti banyaknya perubahan tatanan sosial budaya. keberadaan internet banyak menimbulkan perubahan yang cukup besar bagisiswa sehingga , siswa dapat mengakses berbagai macam informasi, materi-materi pelajaran secara mandiri dan dapat dijadikan sebagai motivasi belajar. Pembelajaran fisika berbasis website peneliti anggap cocok dilakukan dalam situasi tersebut. Konsep pembelajaran berbasis websit memungkinkan siswa untuk dapat belajar dengan mandiri, menyelesaikan tes tutorial, diskusi, chatting, bahkan mengikuti evaluasi melalui media website. Dengan konsep tersebut, siswa mampu berdiskusi secara online dan dipandu untuk mengemukakan pertanyaan yang baik untuk mendorong kemampuan siswa. Media pembelajaran online yang telah dilakukan menunjukan bahwa media pembelajaran online sangat efektif dalam meningkatkan hasil belajar siswa dengan nilai efektifitas terendah 52,00\% sampai tertinggi $94,47 \%$ dengan rata-rata $79,05 \%$
\end{abstract}

Kata kunci: meta analisis ,sikap belajar,motivasi,mandiri.

\section{ABSTRACT}

In Indonesia, the development of the internet has developed quite rapidly. This can be seen from the spread of various internet service providers, the mushrooming of internet cafes / cafes and affordability of internet eccess in term of cost. Nowadays internet technology is no longer considered a luxury item it has even become become a necessity. The internet has had as many in the social and cultural order. The existence of the internet gives rise to many significant changes of students so that students can acces various kind of information, subjek matter independently and can be used as motivation for learning. Physics-based learning website researchers deem appropriate to do in the situation. The concept of web-based learning allows students to be able tu study independently, complete tutorials tests, discussions, chat, and even take part in evaluations trough website media. With this concept, students are able to discuss online and be guided to raise good questions to encourage students' abilities. Online learning media that have been done show that online learning media is very effective in improfing student learning outcomes with the lowes value of effectiveness $52 \%$ to higest $94,47 \%$ with an average $97,05 \%$

Keywords : meta-analysis, learning attitude, motivation, independent

\section{PENDAHULUAN}

Dalam waktu yang relatif singkat internet berkembang ke seluruh dunia, tidak terkecuali Indonesia. Di Indonesia, perkembangan internet mengalami perkembangan yang cukup pesat. Hal tersebut dapat dilihat dari merebaknya berbagai penyedia jasa layanan internet, menjamurnya warung/kafe internet, dan keterjangkauan akses internet dari segi biaya.Dewasa ini teknologi internet sudah tidak dianggap barang mewah lagi, bahkan sudah menjadi kebutuhan. Internet menimbulkan dampak seperti banyaknya perubahan tatanan sosial budaya. Sebagai contoh di bidang ekonomi berkembang. Layanan jual beli dalam jaringan (e-commerce). Dibidang pemerintah telah berkembang istilah layanan pemerintah berbasis dalam jaringan (e-government). Dibidang informasi muncul berita elektronik (enews), sedangkan pada sector pendidikan muncul pembelajaran dalam jaringan (elearning dan online learning). Pembelajaran elektronik baik yang mode online maupun offline keduanya dapat memenuhi prinsip belajar mandiri pada diri siswa (Mohammad Dzamil M. Nur 
2017). Angkowo (2007) menyatakan keberadaan internet banyak menimbulkan perubahan yang cukup besar bagi seseorang untuk berkomunikasi, berinteraksi, berdiskusi dan melakukan penelitan dengan teknologi internet, siswa dapat mengakses berbagai macam informasi, materi-materi pelajaran secara mandiri dan dapat dijadikan sebagai motivasi belajar (Mohammad Dzamil M. Nur 2017). Cheryl (2003), menyatakan kemandirian belajar adalah belajar mandiri yang tidak tergantung pada subyek yang dipelajari atau metode instruksional yang digunakan, namun sebaliknya tergantung pada siapa yang bertanggung jawab, apa yang harus dipelajari, siapa yang harus belajar, metode dan sumber daya apa yang harus digunakan dan bagaimana pengukurannya. Hal senada juga diperjelas Uno (2008), bahwa siswa yang belajar haruslah berperan secara aktif membentuk pengetahuannya sendiri. Salah satu mata pelajaran di jenjang SMA/MA adalah pelajaran fisika. Pelajaran fisika merupakan salah satu mata pelajaran yang dipandang momok oleh sebagian siswa. Hal itu dapat terlihat dari nilai fisika siswa madrasah, pada semester ganjil dan semester genap kelas XI tahun pelajaran 2012/2013, masih banyak siswa yang belum mencapai nilai kriteria ketuntasan minimal (KKM) 75 .

Salah satu penyebab rendahnya capaian nilai KKM siswa diantaranya teknik dan penjelasan guru di kelas tidak menarik bagi siswa. Dengan demikian perlu disiasati proses pengemasan pesan mata pelajaran fisika yang dapat ditampilkan dalam halamanhalaman web yang interaktif. Prabu dan Markus (2006) menjelaskan penggunaan media visual dalam proses pembelajaran fisika dapat menjembatani materi yang bersifat abstrak menjadi konkrit. Penggunaan media pembelajaran akan sangat membantu keefektifan proses pembelajaran dan penyampaian pesan dan isi pelajaran pada saat itu (Arsyad, 1996) Usman dan Asnawir (2002) menyatakan penggunaan media secara kreatif akan memungkinkan siswa untuk belajar lebih baik dan dapat meningkatkan pemahaman mereka. Belajar fisika tidak cukup hanya dengan menguasai matematika. Para siswa diharapkan mampu memahami konsep yang terkandung di dalamnya, menuliskannya ke dalam parameter-parameter atau symbol-simbol fisis, memahami permasalahan serta menyelesaikannya secara matematis. Namun ternyata hal inilah yang menyebabkan rendahnya tingkat kesukaan siswa terhap mata pelajaan fisika (Sugiharti, 2005) Pembelajaran fisika berbasis website peneliti anggap cocok dilakukan dalam situasi tersebut. Konsep pembelajaran berbasis websit memungkinkan siswa untuk dapat belajar dengan mandiri, menyelesaikan tes tutorial, diskusi, chatting, bahkan mengikuti evaluasi melalui media website. Dengan konsep tersebut, siswa mampu berdiskusi secara online dan dipandu untuk mengemukakan pertanyaan yang baik untuk mendorong kemampuan siswa (Min, 2008). Instruksi pembelajaran berbasis website dapat menjadi media yang efektif untuk meningkatkan kemampuan siswa apabila didesain sesuai dengan ketentuan pembelajaran berbasis websit (Varaki, 2006).

Berdasarkan penjelasan diatas maka banyak penelitian menggunakan elearning untuk mengetahui pengaruh dan efektif tidaknya dan lain-lain saat penerapan didalam kelas. Maka kami melakukan penelitian ini untuk mengetahui apakah penggunaan media pembelajaran online efektif dalam meningkatkan hasil sikap belajar siswa.didalam kelas dari beberapa penelitian yang sudah ada. Sehingga guru dapat menimbang untuk menggunakan di dalam kelas.

\section{METODE PENELITIAN}

Penelitian ini termasuk jenis penelitian meta-analisis merupakan suatu teknik statistika untuk menggabungkan 2 atau lebih penelitian sejenis sehingga diperoleh paduan data secara kuantatif (ruswana anwar, 2005) pengumpulan data dalam penelitian ini dilakukan dengan menelusuri jurnal-jurnal pada situs google scholar (scholar.google.co.id) dengan kata kunci "hasil belajar online (e-learning)". Dari pencarian tersebut didapatkan 10 jurnal yang memenuhi kriteria yang kemudian dilakukan analisis. Analisis dilakukan dengan pembandingan untuk menentukan pengaruh penerapan pembelajaran online.nilai dari hasil uji setiap penelitian diambil untuk menentukan tingkat efektif tindakan pembelajaran terhadap sikap belajar siswa.

\section{HASIL DAN PEMBAHASAN}

Hasil penelitian yang dilakukan dalam meta-analisis adalah: 1). Penerapan media e-learning berbasis schoology untuk meningkatkan aktivitas dan hasil belajar materi usaha dan energi dikelas XI SMAN 10 kota Jambi oleh Tugiyoaminoto dan hairul pathoni; 2). Dampak Pembelajaran Daring terhadap penguatan literasi Informasi Dalam Budaya Akademik Mahasiswa. Oleh Asep Nursobah, Ujang Dedih, Hafid, dan Nurhamzah; 3). Perkembangan bahan ajar fisika berbasis e-learning pada teori kinetik gas pada sekolah menengah atas oleh Deri Utami Alfitri; 4). Pengembangan program pembelajaran fisika SMA berbasis e-learning dengan schoology oleh Iamu Wahyudi; 5). Pengembangan portal e-learning berbasis moodle pada mata pelajaran fisika kelas $\mathrm{X}$ di SMA dwijendra Dempasar oleh I Komang Agus Hartawan, I Dewa Kade Tastra dan dan Ketut Pudjawan; 6). ELearning dengan schoology sebagai suplemen Pembelajaran Fisika Materi elastisitas dan hokum hooke 
oleh Nur Hasanah, Eko Suyanto dan Wayan Suana; 7). Keefektifan E-Learning Sebagai Media Pembelajaran (Studi Evaluasi Model Pembelajaran Elearning SMK Telkom Sandhy Putra Purwokerto) oleh Numiek Hanum; 8). Efektivitas Pembelajaran Daring menggunakan media Online selama Pandemi Covid-19 Pada Mata Pelajaran Matematika Oleh Mustakim; 9). Pembelajaran online berbasis proyek Salah satu solusi kegiatan belajar ditengah pandemic covid- 19 oleh zainal Abidin, Rumansyah, dan Kurniawan Arizona; 10). Pengembangan E-learning Berbasis Schoology Pada Materi Impuls dan Momentum Untuk Melatihkan Literasi Digital oleh Misbah, Wahyu Aji Pratama,Sri Hartini, dan Dewi Dewantara. Data pada laporan yang dipakai masih sangat luas dan banyak. Dalam laporan ini, data selanjutnya data dilaporkan kembali secara deskriptif kuantatif dan kualitatif hasil analisis terkait dengan pengaruh pembelajaran online dan siakp siswa. Hasil analisis terkait dengan media pembelajaran fisika online dilihat pada tabel.1.

Tabel 1. Hasil analisis media pembelajaran fisika online

\begin{tabular}{|c|c|c|c|}
\hline No & Judul penelitian & Peneliti & $\begin{array}{l}\text { Nilai } \\
\text { efektifitas } \\
\text { pada fisika } \\
\text { online } \\
\text { pada hasil } \\
\text { belajar }(\%)\end{array}$ \\
\hline 1 & 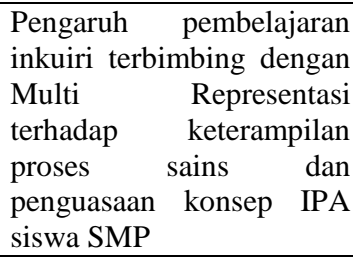 & Muhammad Rizal & 82,47 \\
\hline 2 & $\begin{array}{l}\text { Pengaruh penggunaan } \\
\text { bahan ajar online terhadap } \\
\text { prestasi mahasiswa } \\
\text { Universitas Terbuka }\end{array}$ & $\begin{array}{l}\text { Etty Puji Lestari } \\
\text { Gunoro } \\
\text { Nupikoso } \\
\text { Etik Ipda Ryani }\end{array}$ & 90,00 \\
\hline 3 & $\begin{array}{l}\text { Perkembangan ELearning } \\
\text { Berbasis Schoology Pada } \\
\text { Materi Impuls Dan } \\
\text { Momentum Untuk Melatih } \\
\text { Literasi Digital }\end{array}$ & $\begin{array}{l}\text { Misbah, Wahyu Aji } \\
\text { Pratama, Sri Hartini } \\
\text { dan } \\
\text { Dewi Dewantara }\end{array}$ & 52,00 \\
\hline 4 & $\begin{array}{lr}\text { Penerapan } & \text { Media E- } \\
\text { Learning } & \text { Berbasis } \\
\text { Schoology } & \text { Untuk } \\
\text { Meningkatkan } & \text { Aktivitas } \\
\text { Dan Hasil Belajar Materi } \\
\text { Usaha Dan Energi Di } \\
\text { Kelas Xi SMA N 10 Kota } \\
\text { Jambi }\end{array}$ & $\begin{array}{l}\text { Tugiyo Aminoto \& } \\
\text { Hairul Pathoni }\end{array}$ & 82,81 \\
\hline 5 & $\begin{array}{l}\text { Pengembangan ELearning } \\
\text { Menggunakan Chamilo } \\
\text { Untuk Membantu Proses } \\
\text { Pembelajaran Fisika SMA } \\
\text { Kelas X Semester II }\end{array}$ & $\begin{array}{l}\text { Ayu Rezky Yulita, } \\
\text { Diah Ambarwulan, } \\
\text { Fauzi Bakri }\end{array}$ & 94,47 \\
\hline 6 & $\begin{array}{lr}\text { Pengaruh } & \text { Blended } \\
\text { Learning } & \text { Terhadap } \\
\text { Penguasaan Konsep dan } \\
\text { Penalaran Fisika Peserta } \\
\text { Didik Kelas X }\end{array}$ & $\begin{array}{l}\text { Hermawanto } \\
\text { S Kusairi } \\
\text { Wartono }\end{array}$ & 92,44 \\
\hline 7 & Pembelajaran & Wiwi Mulyani & 70,00 \\
\hline
\end{tabular}

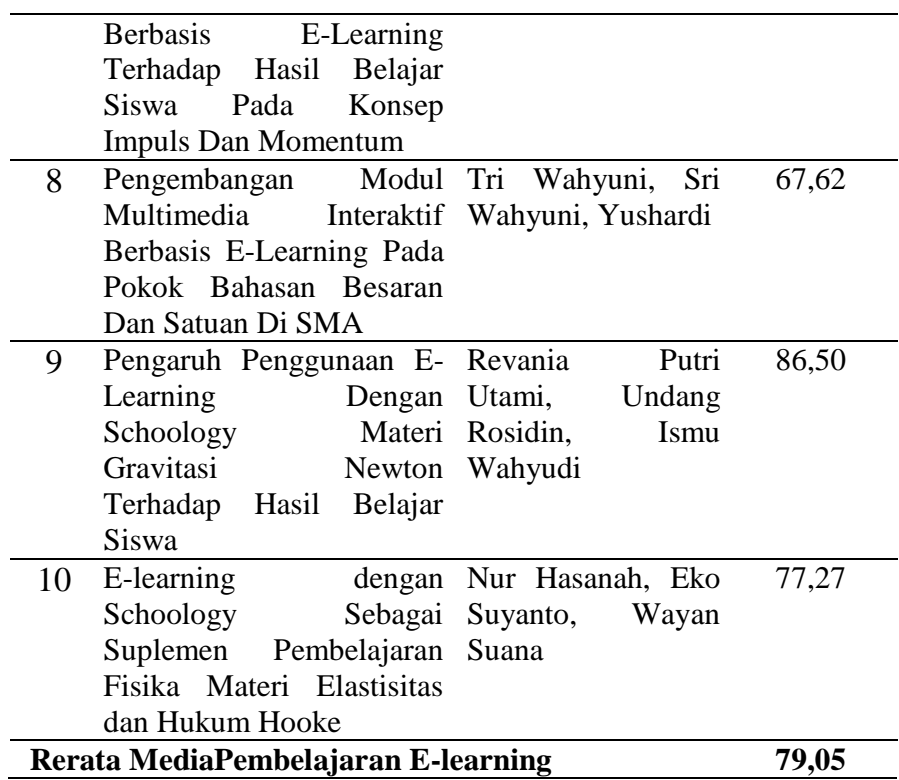

Berdasarkan hasil analisis di atas, dapat di lihat bahwa ternyata media pembelajaran elearning masih sangat efektif di gunakan dalam meningkatkan hasil belajar siswa. Berdasarkan hasil-hasil penelitian tersebut, dapat dilihat bahwa untuk memotivasi peserta didik baik secara intrinsik maupun ekstrinsik, penggunaan elearning dalam proses pembelajaran harus memperhatikan prinsip prinsip penggunaan serta kelebihan dan kekurangan e-learning. Proses pembelajaran dengan menggunakan media online hendaknya tidak menempatkan peserta didik hanya sebagai "pendengar" atau "penonton" saja, melainkan mendorong partisipasi aktif dan peserta didik untuk berinteraksi, berdialog, bekerja sama, berbagi dan membangun pengetahuan bersama. Selain itu dalm menggunakan media online guru harus kreatif dan inovatif serta memiliki sikap kritis dalam memilih bahan pelajaran, beretika baik dalam memanfaatkan bahantersebut, menghindari gambar-gambar atau penggunaan audio yang kurang relevan dengan materi pembelajaran, mendorong partisipasi aktif dari peserta didik,meluangkan waktu lebih bagi peserta didik dan sabar membimbing peserta didik yang mengalami kesulitan dalam menggunakan e-learning. Sehingga dapat di analisis bahwa perbedaan hasil penelitian yang dilakukan oleh peneliti satu dengan peneliti lainnya dikarenakan faktor internal dan faktor eksternal. Faktor internal dari diri siswa yaitu tingkat kemampuan dan kecerdasan yang berbedabeda, kondisi siswa saat melakukan penelitian sehingga tidak maksimal. Faktor eksternalnya bisa dari latar belakang tempat penelitian yang berbeda-beda sehingga mempengaruhi hasil penelitian.

\section{KESIMPULAN}

Penelitian ini menyimpulkan bahwa penggunaan bahan ajar online memiliki pengaruh yang positif terhadap peningkatan nilai siswa, yang sebagian besar menggunakan 
metode perhitungan yang dapat menyulitkan siswa dalam belajar mandiri. Oleh karena itu keberadaan bahan ajar online seperti zoom,wa group, classroom, edmodo, terbukti sangat membantu siswa terlebih di saat sekarang ini. Media pembelajaran online yang telah dilakukan oleh para peneliti menunjukan bahwa media pembelajaran online sangat efektif dalam meningkatkan hasil belajar siswa dengan nilai efektifitas terendah $52,00 \%$ sampai tertinggi $94,47 \%$ dengan rata-rata $79,05 \%$.

\section{DAFTAR PUSTAKA}

Wahyuni, T., Wahyuni, S., \& Yushardi, Y. (2017). Pengembangan modul multimedia interaktif berbasis e-learning pada pokok bahasan besaran dan satuan di SMA. Jurnal Pembelajaran Fisika, 6(4), 404-410.

Utami, R. P., Rosidin, U., \& Wahyudi, I. (2017). Pengaruh Penggunaan E-Learning Dengan Schoology Materi Gravitasi Newton Terhadap Hasil Belajar Siswa. Jurnal Pembelajaran Fisika, 5(2).

Hasanah, N., Suyanto, E., \& Suana, W. (2016). E-learning dengan Schoology Sebagai Suplemen Pembelajaran Fisika Materi Elastisitas dan Hukum Hooke. Jurnal Pembelajaran Fisika, 4(2)

Hartawan, I. K. A., Tastra, I. D. K., \& Pudjawan, K. (2014). Pengembangan portal e-learning berbasis moodle pada mata pelajaran fisika kelas x di sma dwijendra denpasar. Jurnal Edutech Undiksha, 2(1).

Alfitri, D. U. (2013). Pengembangan Bahan Ajar Fisika Berbasis E-learning pada Materi Teori Kinetik Gas Sekolah Menengah Atas (Doctoral dissertation, Universitas Negeri Padang).

Wahyudi, I. (2017). Pengembangan program pembelajaran fisika sma berbasis e-learning dengan schoology. Jurnal Ilmiah Pendidikan Fisika Al-BiRuNi, 6(2), 187-199

Yulita, A. R., Ambarwulan, D., \& Bakri, F. (2018). Pengembangan E-Learning Menggunakan Chamilo Untuk Membantu Proses Pembelajaran Fisika SMA Kelas X Semester II. Gravity: Scientific Journal of Research and Learning Physics, 4(2).

Indrawati, S. (2007). Peningkatan Kemampuan Bernalar Siswa didik melalui pembelajaran konstruktivitas. Jurnal Pengembangan Manusia edisi 5

Aminoto, T. (2014). Penerapan media e-learning berbasis schoology untuk meningkatkan aktivitas dan hasil belajar materi usaha dan energi di kelas xi sma n 10 kota jambi. Sainmatika: Jurnal Sains dan Matematika Universitas Jambi, 8(1).
Hartawan, I. K. A., Tastra, I. D. K., \& Pudjawan, K. (2014). Pengembangan portal e-learning berbasis moodle pada mata pelajaran fisika kelas $\mathrm{x}$ di sma dwijendra denpasar. Jurnal Edutech Undiksha, 2(1).

Hermawanto.(2012).Pengaruh Blended Learning Terhadap Penguasaan Konsep dan Penalaran Fisika Peserta Didik Kelas X di SMA N 1 Batu Malang. Jurnal pendidikan fisika Indonesia 9,67-76. 